\title{
Malign plevral efüzyon
}

\section{Malignant pleural effusion}

\author{
'aRasih YAZKAN \\ 'Süleyman Demirel Üniversitesi Tıp Fakültesi Göğüs Cerrahisi Anabilim Dalı, Isparta, Türkiye
}

\section{öz}

Malign plevral efüzyon tedavisinde plörodez uygulanımı sıklıkla başvurduğumuz bir tedavi yaklaşımıdır. Plörodez için ucuz, etkili, az yan etkiye sahip, kolay temin edilebilen ve kolay uygulanabilenler ajan arayışı devam etmektedir.. Bu makale ile malign plevral efüzyon ve plörodeze hızlı bir bakış amaçlanmıştır.

Anahtar kelimeler: Malign, plevral efüzyon, plörodez

\section{ABSTRACT}

Pleurodesis is a frequent treatment approach for malignant pleural effusion. The search for an agent which is cheap, effective, with minimal side effects, readily available and simply applicable is still going on. This article aimed a rapid overview to malignant pleural effusion and pleurodesis.

Key words: Malignant, pleural effusion, pleurodesis

\section{Giriş}

Malignite, plevral efüzyonun etiyolojisinde daima akılda tutulmalı ve ayırıcı tanıda düşünülmelidir. Plevral boşluğa yakın bir organdan kaynaklanan veya metastaz yapma özelliğine sahip bütün tümörler plevral efüzyona sebep olabilirler. Akciğer kanseri, malign plevral efüzyonların \%40-50'sine sebep olur. Bunu meme kanseri, over kanseri, hodgkin lenfoma, non-hodgkin lenfoma, gastrik kanserler, hepatik tümörler, pankreatik kanserler, karsinoid tümörler, mezotelyoma, özofagus kanseri, akciğerin primer lenfoması, timus kanserleri, sarkomlar ve kulak burun boğaz tümörleri takip eder (Tablo 1) [1].
Tümörün lokal ve sistemik etkileri ve aynı zamanda tedavide kullanılan radyoterapi ve kemoterapinin etkileri ile oluşan paramalign plevral efüzyonlar da önemli bir klinik parametredir [2]. Paramalign plevral efüzyonlar, tümörün lokal etkisine bağlı lenfatik obstrüksiyon, bronşiyal obtrüksiyon sonucu oluşan pnömoni ve atelektazi ile birlikte, hapsolmuş akciğer, şilotoraks ve vena kava süperior sendromu nedeniyle oluşanlar, tümörün sistemik etkisine bağlı pulmoner emboli ve hipoalbuminemi nedeniyle oluşanlar ve radyoterapinin erken ve geç komplikasyonları yanısıra metotreksat, prokarbazin, siklofosfamid, mitomisin ve bleomisin gibi kemoterapotiklerin sistemik etkilerine bağlı oluşanlar şeklinde sıralanabilirler (Tablo 2) [2]. 
Tablo 1. Malign Plevral Efüzyon Nedenleri

\author{
Akciğer kanserleri \\ Meme kanseri \\ Over kanseri \\ Hodgkin lenfoma \\ Non-hodgkin lenfoma \\ Gastrik kanser \\ Hepatik tümörler \\ Pankreatik kanserler \\ Karsinoid tümörler \\ Mezotelyoma \\ Özofagus kanseri \\ Akciğerin primer lenfoması \\ Timus kanserleri \\ Sarkomlar \\ Kulak Burun Boğaz tümörleri
}

\section{Patofizyoloji}

Hemen hemen bütün kanserler plevraya metastaz yaparlar. Akciğer kanserleri plevraya en sık metastaz yapan tümörlerdir, çünkü plevra ile çevrilidirler, bu duruma kitlenin pulmoner artere invaze olması ve visseral plevraya emboli olması önemli bir etken olarak belirtilmiştir [2].

Malignitelerde büyük miktarlarda plevral sıvı birikiminin en önemli sebebi bozulmuş lenfatik drenajdır. Mediastinal ve parasternal (internal mammarial) lenf nodlarının pariyetal plevradaki stomalarının kapanarak lenfatik drenajın bloke olması mekanizmayı belirler [2]. Bununla birlikte plevraya tümör invazyonu sonucu gelişen inflamatuar cevap mikrovasküler permeabilitedeki artışla plevral efüzyon birikimini tetiklemektedir. Diğer muhtemel sebepler arasında oksijen radikalleri, araşidonik asit radikalleri, proteazlar, lenfositler ve immün kompleksler sayılabilmektedir [2]. Malign mezoteliomada erken belirti olan plevral efüzyon hem plevral yüzeydeki lenfatik drenajın bozulmasından hem de direkt plevral invazyonla kapiller permeabilitenin bozulmasından kaynaklanmaktadır. Tümör progresyon gösterdikce visseral ve pariyetal plevra yapışmakta ve plevral sıvı azalmakta ya da yok olmaktadır [2]. Otopsi serileri göstermiştir ki, akciğer kanserli hastalarda visseral ve pariyetal plevra yüzeylerinde metastaz sıklıkla görülmektedir. Akciğer kanserlerinde visseral plevra tutulumu kitlenin direk yayılımı ile ya da pulmoner arter invazyonu ve embolisi ile olmaktadır. Plevra boşluğuna tümör hücresi ekilimi visseral plevradan pariyetal plevraya doğru olmakta ve bu da tümörün plevral adezyonunun artmasına yol açmaktadır [2].

\section{Klinik bulgu ve belirtiler}

Malign plevral efüzyonda klinik tablo değerlendirildiği zaman plevra tutulumu ve fazla miktarda plevral efüzyon oluşumu sonucu sıklıkla dispne karşımıza çıkmaktadır. Diffüz plevral mezoteliomalı hastalarda dispne ve göğüs ağrısı şikayeti vardır, bazı hastalar ise asemptomatik olur ve rutin akciğer grafilerinde plevral efüzyon tespit edilebilir. Plevranın malign invazyonu olan hastalar kilo kaybı ve kronik hastalık hali içindedirler. Pariyetal plevra, kotlar ve göğüs duvarı tutulumu sonucu göğüs ağrısı gelişmektedir [2].

Tablo 2. Paramalign Plevral Efüzyon Nedenleri

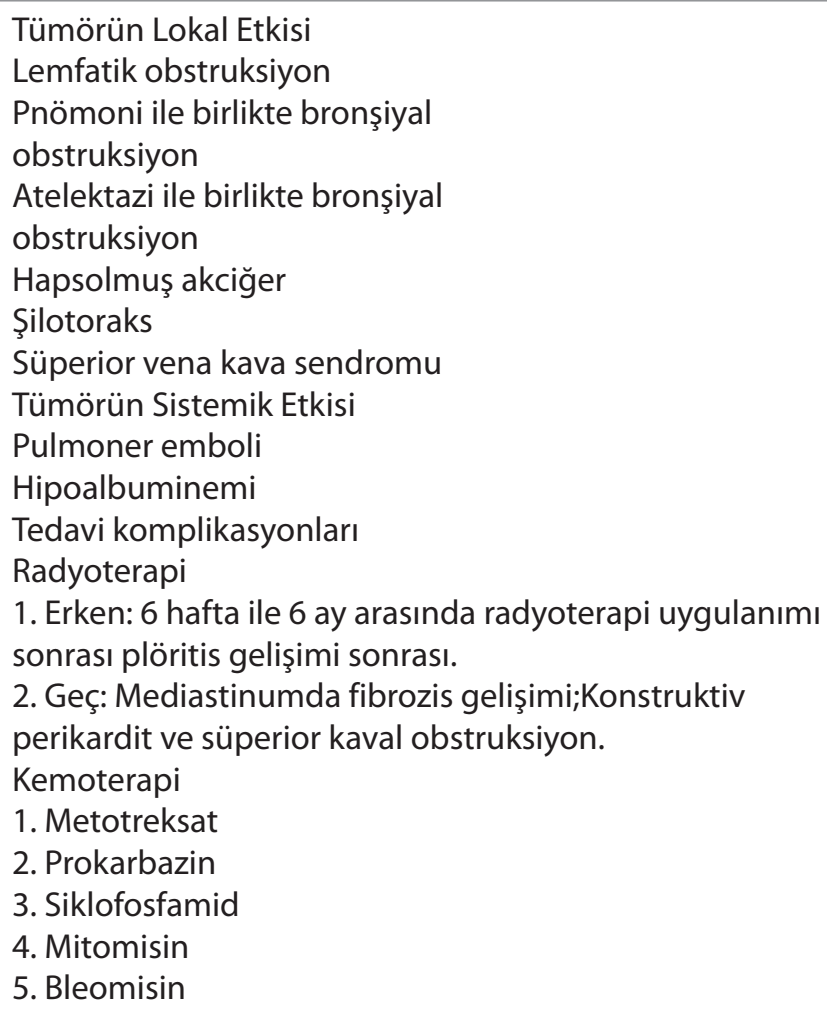

\section{Tanı yöntemleri}

Malign plevral efüzyonda tanı yöntemleri içinde, torasentez, plevra biyopsisi, plöroskopi, torakoskopi ve VATS (video assisted thoracoscopic surgery), torakotomi, ve radyolojik bulgular şeklinde sıralanabilir (Tablo 3) [2,3].

\section{Malign plevral efüzyon özellikleri}

Malign plevral efüzyon seröz, serözanjinöz ve hemorajik olabilir. Belirgin kanlı plevral efüzyon direk plevral tutulumunu düşündürmektedir. Seröz efüzyon ise sıklıkla lenfatik obstrüksiyon veya endobronşial lezyona bağlı atelektazi sonrası oluşur. Malign plevral sıvının özellikleri: Makroskopik olarak; non spesifiktir, kanlı olabilir, biyokimyasal olarak; protein $>3 \mathrm{gr} /$ $\mathrm{dL}$, LDH >200 U, glukoz <60 mg/dL, pH <7,3, amilaz >160 U, patolojik olarak; sitolojik veya histopatolojik değerlendirmede malign hücreler görülebilir şeklindedir (Tablo 4) [4,5].

Tablo 3. Malign Plevral Efüzyonda Tanı Yöntemleri

Torasentez
Plevra biyopsisi
Plöroskopi
Torakoskopi
VATS (video assisted thoracoscopic surgery)
Torakotomi
Radyolojik bulgular


Tablo 4. Malign Plevral Efüzyonun Özellikleri

\begin{tabular}{|l|}
\hline Makroskopik görünüm \\
Non spesifiktir, kanlı olabilir \\
Biyokimyasal değerler \\
Protein $>3 \mathrm{gr} / \mathrm{dL}$, \\
$\mathrm{LDH}>200 \mathrm{U}$, \\
$\mathrm{Glukoz}<60 \mathrm{mg} / \mathrm{dL}$, \\
$\mathrm{pH}<7, .3$ \\
Amilaz $>160 \mathrm{U}$ \\
Patoloji \\
Sitoloji ve/veya histoloji (+) \\
\end{tabular}

\section{Tedavi}

Malign ya da paramalign plevral efüzyon tespit edilen ve cerrahi planlanmayan hastalarda klinisyen palyatif amaçlı tedavi düşünmelidir. Bu kararı düşündüren ise hastanın kondüsyonu, semptomları ve sağkalım süresidir. Tedavi yaklaşımı, plöredezisden plörektomiye kadar değişiklik gösterebilir. Sistemik kemoterapi malign plevral efüzyonun kontrolünde anlamlı katkı sağlamamıştır, ancak lenfoma, meme kanseri ve küçük hücreli akciğer kanseri kemoterapiden fayda görmektedir [2].

Tedavi planında primer tümörün yeri ve histolojisi, hastanın semptomları ve genel medikal durumu ve eşlik eden hastalıkları gözönüne alınmalıdır. Beklenen yaşam süresi de tedavi seçimini etkiler. Tedavinin amacı, minimum morbidite ile semptomlarda kalıcı bir iyileşme sağlamak olmalıdır. Malign plevral sıvılı hastalarda kür, yani tam iyileşme şansı genellikle yoktur. Tedavi palyatiftir ve palyasyon semptomların giderilmesi olarak tanımlanmaktadır. Malign plevral sıvıda en belirgin semptom sıvının miktarı ile orantılı olarak akciğerde gelişen pasif atelektazi nedeniyle oluşan dispnedir. İkinci önemli semptom ise göğüs ağrısıdır. Dolayısı ile tedavinin amacı dispnenin kontrol edilmesidir, efüzyonun tamamen ve kalıcı olarak kontrolü optimum tedavi sonucunu verecektir. Bazı hastalarda parenkimal hastalıkta plevral sıvıya eşlik eder. Bu durumda sıvının kontrolü ile dispnenin tamamen düzelmesi mümkün olmaz. Çünkü dispne yapan parankimal hastalık sürmektedir. Seçilen tedavi yöntemi hayat kalitesini korumaya veya artırmaya yönelik olmalıdır [6,7].

Tedavi seçenekleri, torasentez, plörektomi, radyoterapi, tüp torakostomi [4,8-10] ve kimyasal plörodez, VATS ve torakoskopi yardımlı plörodez [4,11-14] plöroperitoneal şant $[4,15,16]$ plevral kateter uygulanması $[4,16,17]$ ince lümenli kateterler [4,18-21] şeklindedir (Tablo 5).

Tablo 5. Malign Plevral Efüzyon Tedavi Seçenekleri

Torasentez
İnce lümenli kateterler
Tüp torakostomi
Vats ve torakoskopik plörodez
Kimyasal plörodez
Plörektomi
Radyoterapi
Plöroperitoneal şant

\section{Plörodez}

Plevral sıvı drenajı ve kimyasal plörodez, malign plevra efüzyonunun tedavisinde en sık kullanılan yöntemdir. Drenajın ardından plevral aralığa sklerozan ajan verilmesi hem daha az maliyet içermesi ve daha az morbid olması, hem de semptomların kontrolünün sağlanması açısından önemlidir [4]. Plörodez uygulanmadan önce semptomların, özellikle de nefes darlığının direkt olarak sıvı ile ilişkili olup olmadığının, sıvının tekrarlayıcı olup olmadığının, akciğer ekspansiyonun sağlanıp sağlanamayacağının ve yaşam beklentisinin ne kadar olduğunun belirlenmesi gerekir [4,7]. Plörodez için drenajı takiben özellikle hapsolmuş akciğerin olmadığı mutlaka belirlenmelidir, çünkü bu durumda iki plevranın karşılıklı gelememesi nedeni ile plevral yapraklarda yapışmanın olması mümkün değildir. Plörodezi etkileyen diğer önemli durumlar ise; plevra sıvısının tamamen boşalması, sklerozan ilacın tüm plevra yüzeylerine temasının sağlanması ve kimyasal plörit ve yapışmanın oluşmasına kadar iki plevra yaprağının karşılıklı temasının devam ettirilmesidir [7].

Plörodez yaklaşımı ile ilgili literatür değerlendirildiği zaman bir çok ajanın çalışıldığını ancak ideal plörodez ajanı arayışının devam ettiğini görmekteyiz. 20. yüzyılın başlarından günümüze kadar geçen süreçte plörodez amaçlı çok sayıda ajan klinik ve deneysel çalışmalarda kullanılmıştır. Kullanılan tüm ajanların başarı oranları farklıdır ve bazı yan etkileri vardır $[22,23]$. En etkili ajanın hangisi olduğuna dair bir ortak görüş henüz yoktur. Antiinflamatuar ajanların kullanımı, plevral sıvı pH'sının 7,28'in altında olması plörodez başarısını azaltan önemli bir etkenlerdir [23]. Plörodez çalışmalarının amacı en ucuz, en etkili, en az yan etkiye sahip, en kolay temin edilebilen ve uygulanabilen ajana ulaşmaktır, bu amaçla gerek uygulama yöntemlerini gerekse ajanları karşılaştıran birçok klinik ve deneysel çalışma literatürde mevcuttur, etkinlik ve ucuzluk vazgeçilmez parametredir, bu anlamda son yıllarda özellikle otolog kan ve iodopovidon çalışmaları literatürde yer bulmuştur [4,22,24-28]. Doğru hasta seçimi ve uygun teknikler ile malign plevral efüzyonların \%90'dan fazlasında plörodez sağlanabilmektedir. Plörodeze bağlı sıklıkla ateş, göğüs ağrısı, hipotansiyon gibi ortak, akut ve minör komplikasyonlar gelişebileceği gibi, nadiren hayatı tehdit eden akut respiratuar distres sendromu ve pulmoner ödem gibi ciddi komplikasyonlarda bildirilmiştir [7]. Tüm dünyada en sık kullanılan ajan talk'dır. Talk, kolay elde edilebilir, yüksek derecede etkili ve uygun dozda kullanıldığında minimal yan etkiye sahip plörodez ajanıdır [23]. 1935 yılından bu yana plörodez amaçlı olarak kullanılmaktadır. Doğada magnezyum silikat tabakaları halinde ve sıklıkla asbest ile birlikte bulunur. Plörodez amaçlı kullanımı asbestten arındırılmış olarak temin edilebilen steril ticari preparatlarla olmalıdır [22,23].

\section{Sonuç}

Malign plevral efüzyon tedavisinde plörodez uygulanımı sıklıkla başvurduğumuz bir tedavi yaklaşımıdır, bu amaçla birçok ajan kullanılmış ve en ucuz, en etkili, en az yan etkiye sahip, en kolay temin edilebilen ve uygulanabilen ajana ulaşmak amaçlanmıştır, mevcut araştırmalar bu sürecin hız kesmeden devam edeceğini ve yeni ajanların yeni çalışmalarla sunulacağının mutlak bir gerçek olduğunu göstermektedir. 


\section{Çıkar çatışması ve Finansman Beyanı}

$\mathrm{Bu}$ çalışmada çıkar çatışması ve finansman destek alındığı beyan edilmemiştir.

\section{Kaynaklar}

1. Swanson SJ. Batırel HF. Plevral Efüzyon. "Göğüs Cerrahisi"Yüksel M, Kalaycı G, İstanbul, Bilmedya Grup, 2001. 363-9.

2. Sahn SA. Malignant pleural effusions. In: Shields TW, LoCicero III J, Ponn RB, editors. General thoracic surgery. 5th ed. Philadelphia: Lippincott Williams \& Wilkins; 2000. p. 795-804.

3. Mutlu B. Plevra Sıvıları, "Göğüs Hastalıkları" Erk M, İstanbul, Santay San. Ve Tic. Lmt. Şti. 2001, 955-90.

4. Yazkan R, Yıldırım E, Dural K, Zengin N, Sakıncı Ü. Rapid pleurodesis in malignant pleural effusion: a clinical study and literature review. Turkish J Thorac Cardiovasc Surg 2011; 19: 410-6.

5. Soysal Ö. Plevral effüzyonlar. In: Ökten İ, Güngör A, editörler. Göğüs cerrahisi. Ankara: Sim Matbaacılık; 2003. 791-815.

6. Şakul U, Soysal Ö. Toraks Anatomisi, Plevral Efüzyonlar. "Göğüs Cerrahisi" Ökten I, Güngör A. 1. Baskı, Ankara, Sim Matbaacılık Ltd.Şti. 2003.1-76, 791-815.

7. Yıldırım H. Plöredezis başarısını etkileyen moleküler ve biyokimyasal belirteçler. Türk Toraks Derneği Plevra Bülteni 2009; 3: 17-9.

8. Ong KC, Indumathi V, Raghuram J, Ong YY. A comparative study of pleurodesis using talc slurry and bleomycin in the management of malignant pleural effusions. Respirology 2000; 5: 99-103.

9. Jacobi CA, Wenger FA, Schmitz-Rixen T, Müller JM. Talc pleurodesis in recurrent pleural effusions. Langenbecks Arch Surg 1998; 383: 156-9.

10. Walter M, Türler A, Schmitz-Rixen T. Talc pleurodesis in recurrent malignant pleural effusion-a prospective follow-up study. Zentralbl Chir 1996; 121: 216-22.

11. Aelony $Y$, King RR, Boutin C. Thoracoscopic talc poudrage in malignant pleural effusions: effective pleurodesis despite low pleural pH. Chest 1998; 113: 1007-12.

12. Erickson KV, Yost M, Bynoe R, Almond C, Nottingham J. Primary treatment of malignant pleural effusions: videoassisted thoracoscopic surgery poudrage versus tube thoracostomy. Am Surg 2002; 68: 955-9.

13. Tattersall M. Management of malignant pleural effusion. Aust $\mathrm{N}$ Z J Med 1998; 28: 394-6.

14. Önal Ö, Bilgin $M$, Hasdıraz L, Oğuzkaya F, Kahraman A, Erdoğan M. Malign plevral effüzyonun video yardımlı torakoskopi ile palyatif tedavisi. Erciyes Tıp Dergisi 2009; 31: 162-8.

15. Özkan B. Toker A. Malin efüzyonlarda plöro-peritoneal şant. Türk Toraks Derneği Plevra Bülteni 2009; 3: 20-2.
16. Sahn SA. Management of malignant pleural effusions. Monaldi Arch Chest Dis 2001; 56: 394-9.

17. Putnam JB Jr. Malignant pleural effusions. Surg Clin North Am 2002; 82: 867-83.

18. Hsu WH, Chiang CD, Chen CY, Kwan PC, Hsu JY. Ultrasoundguided small-bore Elecath tube insertion for the rapid sclerotherapy of malignant pleural effusion. Jpn J Clin Oncol 1998; 28: 187-91.

19. Saffran L, Ost DE, Fein AM, Schiff MJ. Outpatient pleurodesis of malignant pleural effusions using a small-bore pigtail catheter. Chest 2000; 118: 417-21.

20. Marom EM, Patz EF Jr, Erasmus JJ, McAdams HP, Goodman PC, Herndon JE. Malignant pleural effusions: treatment with smallbore-catheter thoracostomy and talc pleurodesis. Radiology 1999; 210: 277-81.

21. Parulekar W, Di Primio G, Matzinger F, Dennie C, Bociek G. Use of small-bore vs large-bore chest tubes for treatment of malignant pleural effusions. Chest 2001; 120: 19-25.

22. Yazkan R. Pleurodesis Which Agent? J Clin Anal Med 2013; 4(1)DOI: 10.4328/ JCAM.803.

23. Şenyiğit A. Plöredezisde Sık Kullanılan Ajanlar. TTD Plevra Bülteni 2009; 3: 17-9.

24. Yıldırım E, Dural K, Yazkan R, et al. Rapid pleurodesis in symptomatic malignant pleural effusion. European Journal of Cardio-thoracic Surgery 2005; 27: 19-22.

25. Yazkan R, Özpolat B, Ergene G. lodopovidone pleurodesis in the treatment of refractory pleural effusions. Türk Göğüs Kalp Damar Cerrahisi Dergisi 2013;21: 106-9.

26. Yazkan R, Özpolat B, Duman L, Bircan S, Bozkurt KK, Güneş S. Identification of the concentration of iodopovidone pleurodesis in rats for the maximal effectiveness. Türk Göğüs Kalp Damar Cerrahisi Dergisi 2013; 21: 737-42.

27. Gözübüyük A, Özpolat $B$, Çiçek AF, et al. Comparison of side effects of oxytetracycline and talc pleurodesis: an experimental study. J Cardiothorac Surg. 2010; 13: 128. doi: 10.1186/1749-8090-5-128.

28. Özpolat B, Gazyağcı S, Gözübüyük A, Ayva Ş, Atinkaya C. Autologous Blood Pleurodesis in Rats to Elucidate the Amounts of Blood Required for Reliable and Reproducible Results. J Surg Res. 2010 Jun 15; 161: 228-32. 